\title{
Assessment of current and potential yield of hand-dug wells in a semi-arid zone in south-central Chile using an analytical methodology
}

\author{
Hamil Uribe ${ }^{*}$, David E. Rupp², José Luis Arumí ${ }^{3}$, Ryan D. Stewart ${ }^{4}$, and John S. Selker ${ }^{4}$
}

\begin{abstract}
The semi-arid interior dryland region in south-central Chile is characterized by shrink-swell granitic soils and a semi-arid Mediterranean climate, which together cause scarce dry-season surface water supplies. Historically, the lack of easily accessible water has limited the region's economic development. In most of the region's rural communities, the only local water supplies for drinking and small-scale irrigation are shallow, hand-dug wells. The objectives of this study, conducted in the San José catchment in the Biobío Region ( $36^{\circ} 24^{\prime}$ S, $\left.72^{\circ} 30^{\prime} \mathrm{W}\right)$, were to demonstrate the usefulness of a simple aquifer characterization methodology to assess the likelihood of additional extraction of groundwater in this area with existing wells, estimate potential increases in productivity through increases in well depth, and present the spatial distribution of aquifer properties in this area. Hydraulic conductivity values $\left(K_{s}\right)$ were measured from analyses of recovery rates of handdug wells. Values of $K_{s}$ ranged between 0.04 and $5.1 \mathrm{~m} \mathrm{~d}^{-1}\left(\right.$ mean $=1.07 \mathrm{~m} \mathrm{~d}^{-1}$; standard deviation $\left.=1.36 \mathrm{~m} \mathrm{~d}^{-1}\right)$, which resulted in a low yield from the shallow wells. These $K_{s}$ values were used to estimate the potential groundwater yield which could be extracted from hand-dug wells in the region in their current condition with increased pumping and, where feasible, if wells were deepened by $0.5 \mathrm{~m}$. Results suggested that existing wells could produce up to $0.008 \mathrm{~m} \mathrm{yr}^{-1}$ and up to $0.02 \mathrm{~m}$ $\mathrm{yr}^{-1}$ by deepening them. Since current water usage has been estimated as $0.002 \mathrm{~m} \mathrm{yr}^{-1}$, these results suggest that additional groundwater supplies could be exploited.
\end{abstract}

Key words: Groundwater recharge, hydraulic conductivity, interior dryland, slug test, water usage, well capacity.

\section{INTRODUCTION}

The semi-arid region of south-central Chile, known as the Secano Interior (interior dryland), is located on the eastward slope of the Chilean Coastal Mountain Range. Significant poverty exists in this region, partly due to the limited amount of dry-season surface water supplies which constrain agricultural productivity. However, the region's mild Mediterranean climate is ideal for growing a variety of crops, including wine grapes, cherries, olives, flowers, and other valuable annual crops. If additional groundwater resources were secured, the local population could substantially improve their income and selfsufficiency (Pérez and González, 2001).

\footnotetext{
${ }^{1}$ Instituto de Investigaciones Agropecuarias, INIA Quilamapu, Av. Vicente Méndez 515, Chillán, Chile.

*Corresponding author (huribe@inia.cl).

${ }^{2}$ Oregon Climate Change Research Institute, Cooperative Institute for Marine Resources Studies, 326 Strand Ag Hall, Corvallis, OR 97331Oregon, USA.

${ }^{3}$ Universidad de Concepción, Facultad de Ingeniería Agrícola, Av. Vicente Méndez 595, Chillán, Chile.

${ }^{4}$ Oregon State University, Department of Biological and Ecological Engineering, 116 Gilmore Hall, Corvallis, Oregon, USA.

Received: 30 June 2013.

Accepted: 20 March 2014.

doi:10.4067/S0718-58392014000200014
}

The San José Basin is a small catchment in the interior dryland, which possesses demographics, climate, and topography representative of the region as a whole. Administratively, the basin belongs to the Municipality of Ninhue, Ñuble Province, Biobío Region (Figure 1A). A survey conducted in the San José Basin showed the existence of 70 hand-dug wells installed by the local farmers or property owners for domestic use (Uribe et al., 2004). These wells were mostly shallow, and therefore of limited productivity. As a result, current rates of groundwater extraction in the region were far below the rate of aquifer recharge; this which suggests that it may be possible to sustainably extract additional groundwater and support high-value agriculture.

Aquifer properties, such as hydraulic conductivity $\left(K_{s}\right)$ and rate of recovery, can be estimated through well recovery experiments in large-diameter wells which are employed in this area (Mace, 1999; Rupp et al., 2001). These estimates can then be used to predict theoretical well yields. This methodology has been used to quantify spatial water availability distribution in other sectors of the interior dryland (Rupp et al., 2011). Other studies have used pumping tests of large-diameter wells to quantify aquifer properties such as transmissivity and storability, and to derive estimates of potential yield and aquifer geometry (MacDonald et al., 2008). In general, pumping tests require more resources than slug tests, thus 

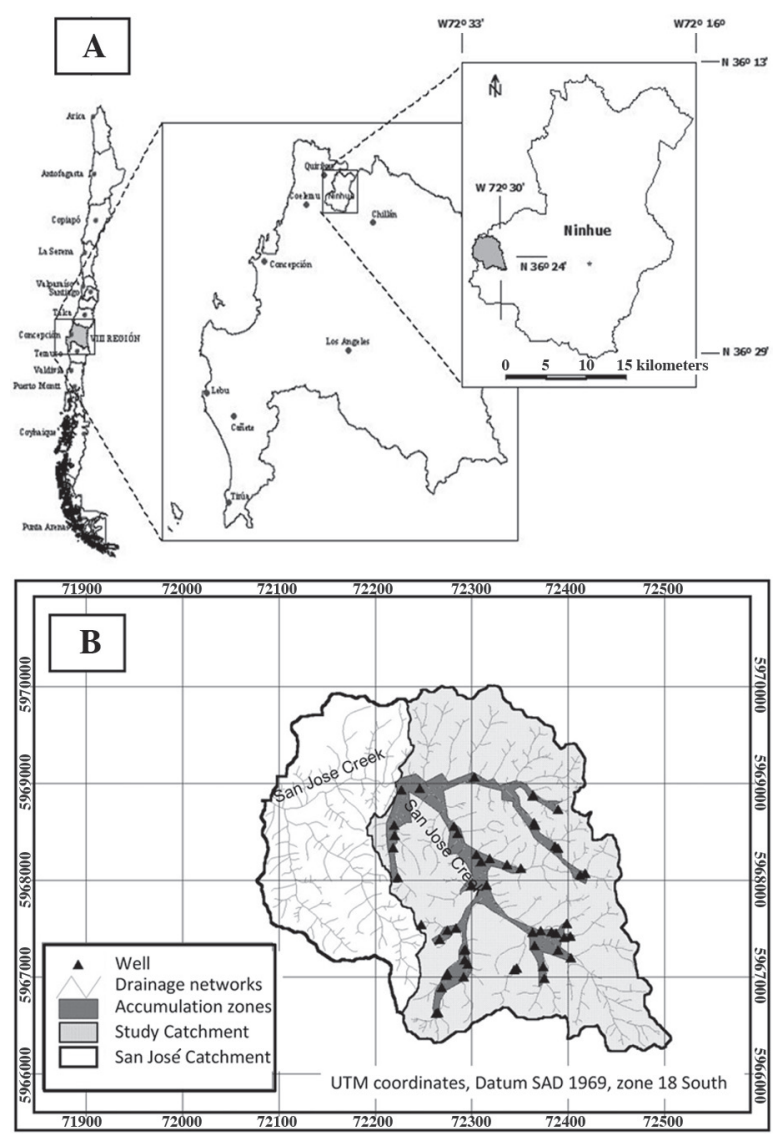

Figure 1. A) General location of the study area. B) Location of hand-dug wells, basins, streams, accumulation zones, and drainage networks.

limiting the number of wells that can be tested because of limited time and resources. Numerical analyses have demonstrated the accuracy of hydraulic conductivity determinations measured with slug tests (Yang and Yeh, 2004). The effects of formation heterogeneity on the apparent aquifer properties from slug tests have been considered in large-diameter wells (Çimen, 2005).

The amount of groundwater that can be sustainably extracted is bounded by the aquifer recharge. A chloride balance study on the Claro River catchment, also located in the interior dryland, resulted in $0.027 \mathrm{~m} \mathrm{yr}^{-1}$ net infiltration (González et al., 1999). Other studies conducted in the Buenos Aires micro-basin, located approximately $20 \mathrm{~km}$ from the current study site in the Municipality of Portezuelo, estimated recharge rates of $0.045 \mathrm{~m} \mathrm{yr}^{-1}$; these would provide enough water to irrigate $5 \%$ of the land surface (Selker et al., 2000). In the San José Basin, groundwater recharge rates were estimated between 0.006 and $0.022 \mathrm{~m} \mathrm{yr}^{-1}$ by using a modification of the water balance model proposed by Thornthwaite (Uribe et al., 2003).

This study had four main objectives: 1) to demonstrate the utility of the methodology by Rupp et al. (2001; 2011) for rapid and accurate determination of aquifer properties in large-diameter wells, 2) to investigate the spatial distribution of aquifer properties in this region, 3 ) to assess the likelihood to extract additional groundwater in this area, and 4) to evaluate the potential to increase well productivity through modest increases in well depth.

\section{MATERIALS AND METHODS}

\section{Site description}

This study was conducted in the San José Basin, located on the eastward slope of the Chilean Coastal Mountain Range, $10 \mathrm{~km}$ west from the town of Ninhue $\left(36^{\circ} 24^{\prime}\right.$ $\left.\mathrm{S}, 72^{\circ} 30^{\prime} \mathrm{W}\right)$ (Figure 1A). The analyzed wells were located in an area representing approximately $70 \%$ of the whole San José Basin (Figure 1B). According to the Papadakis classification system, the region's climate can be described as Mediterranean (del Pozo and del Canto, 1999). Average annual precipitation is $0.775 \mathrm{~m}$ which is concentrated between May and September (Dirección General de Aguas (DGA) weather station located in San Agustín de Puñual, $7 \mathrm{~km}$ from the study area). January and February are the warmest months with a mean daily temperature of $20^{\circ} \mathrm{C}\left(27^{\circ} \mathrm{C}\right.$ average daily maximum and $12{ }^{\circ} \mathrm{C}$ average daily minimum). Potential evaporation is $1.10 \mathrm{~m} \mathrm{yr}^{-1}$ with the highest rates occurring in December, January, and February (CNR-CIREN-CORFO, 1997).

Geology. The basin is comprised largely of Paleozic granite rich in quartz and feldspar (Bizama, 1998). Intense chemical weathering acting against the granitic rocks of the Coastal Mountain Range has created in situ formations of soils belonging to the Cauquenes soil association (Alfisol) (CIREN, 1999). Cauquenes association soils are composed of fine-textured material with a significant fraction of sand at the surface, which causes them to have high erodability and low fertility (González et al., 1999; Selker et al., 2000). The soils can have a high proportion of 2:1 layers of swelling clays. During the rainy season, swelling of clay particles causes the soil surface to seal; this results in low permeability, low infiltration rates through the upper horizons, and concentrated surface runoff (Stewart et al., 2014). The upper soil horizons commonly have a volumetric soil water storage capacity of approximately $20 \%$, whereas in deeper saprolite and native granite layers the effective porosities can be as low as $1 \%$ to $8 \%$ (González et al., 1999; Selker et al., 2000). Overall, these soils have limited ability to contribute to aquifer productivity although localized accumulation and infiltration occurs in low-lying portions of the topography (González et al., 1999).

Drainage and hydraulic network. The 5.44-km long intermittent San José Creek drains into the Santa Rosa Creek before entering the Lonquén River (Figure 1B). The whole San José catchment and the portion used for this study are characterized in Table 1 . The drainage pattern of 
Table 1. Physical description of the San José Basin. Information has been listed for the portion of the basin featured in the study and for the complete basin.

\begin{tabular}{lcc}
\hline Feature & Study Portion & San José Basin \\
\hline Area, $\mathrm{km}^{2}$ & 7252 & 10569 \\
Perimeter, km & 12850 & 14220 \\
Minimum elevation, $\mathrm{m}$ & 55 & 42 \\
Maximum elevation, $\mathrm{m}$ & 230 & 230 \\
Length of the principal channel, $\mathrm{km}$ & 3830 & 5440 \\
Slope of the principal channel, $\mathrm{m} \mathrm{m}^{-1}$ & 0.0193 & 0.015 \\
\hline
\end{tabular}

the study area is influenced by the basin's geomorphology, lithology, and existing structures. The basin has a highlybranched and highly-degraded dendritic drainage network marked by deep and often rapidly advancing gullies.

Location of hand-dug wells and selection of study wells Forty-nine hand-dug wells were geo-referenced with UTM coordinates (Zone 18 South, South American Datum 1969). All the wells were characterized for their diameter, depth, and phreatic level, as well as construction characteristics. The presence of any rock at the bottom of the well was noted since this would impede the ability of the well to be deepened.

The majority of wells in this study were located in "accumulation zones" within the lowland reaches of the drainage networks which are characterized by deposited sediments that are distinct from local soils formed in situ (Figure 1B). Most of the wells were hand-dug with $1 \mathrm{~m}$ diameter by $1 \mathrm{~m}$ height sections of perforated cement tubing to maintain the well structure. Well depths were between $1.48 \mathrm{~m}$ and $10.1 \mathrm{~m}$ with a mean of $4.78 \mathrm{~m}$ (Figure 2a).

A survey of rural farmers revealed that their mean water use $(W)$ was $0.46 \mathrm{~m}^{3} \mathrm{~d}^{-1}$ per well with a maximum of $3 \mathrm{~m}^{3}$ $\mathrm{d}^{-1}$ and a minimum of $0.020 \mathrm{~m}^{3} \mathrm{~d}^{-1}$, which is equivalent to less than $0.002 \mathrm{~m} \mathrm{yr}^{-1}$ (Figure 2b, adapted from Uribe et al., 2004). This information provided an estimate of the actual usage which could then be compared to the estimates of potential well yield found in this study.

Slug recovery tests were performed following the method described by Rupp et al. $(2001 ; 2011)$ on 35 hand-dug wells to estimate the saturated hydraulic conductivity $\left(K_{s}\right)$ of the local aquifer. During these tests, water was removed from the wells at a much faster rate than the rate of recovery. The test method was well-suited to the remote areas under consideration and required only a motorized pump, measuring tape, and data-logging pressure transducer to record the water level. Wells were pumped for 15 to $30 \mathrm{~min}$.

\section{Determination of aquifer hydraulic characteristics}

The well recovery data measured in the large-diameter wells was used to estimate $K_{s}$ according to Rupp et al. (2001). In the present study, we used the special case based on only $25 \%$ and $75 \%$ recovery levels for which the following equations can be used:
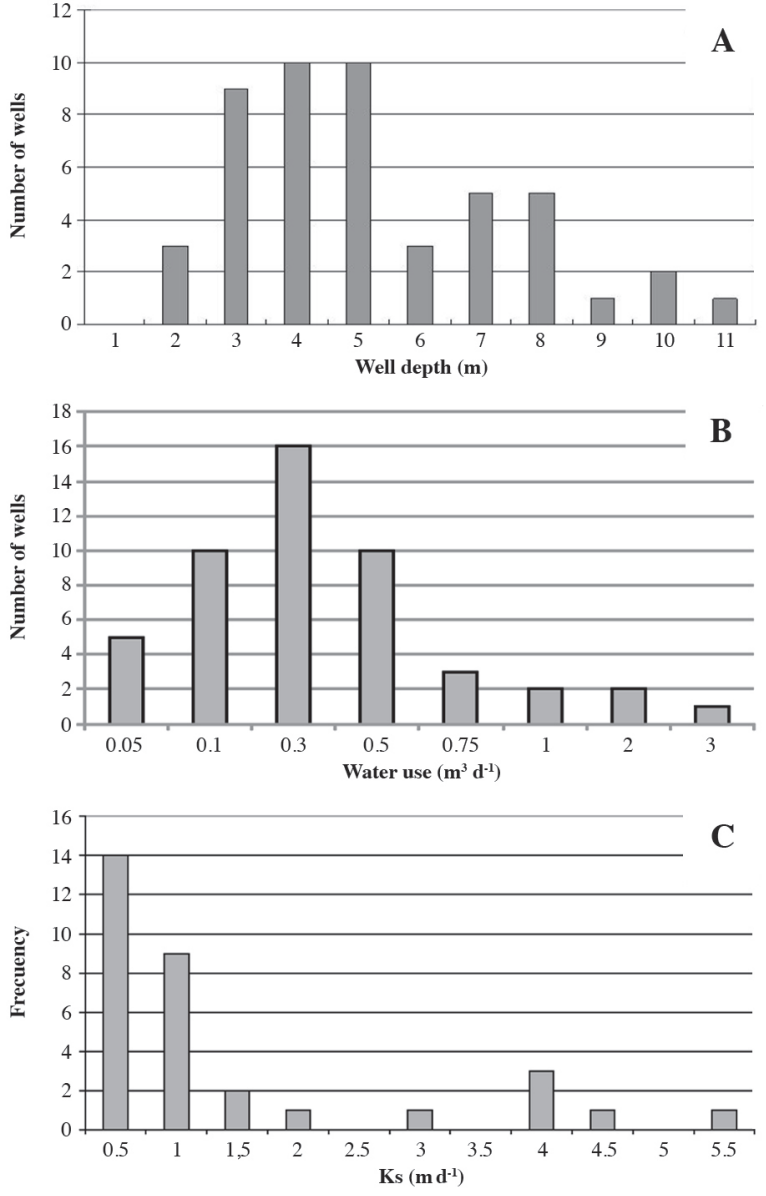

Figure 2. Well characteristics: A) Depth distribution of hand-dug wells in the study area, B) Water usage of hand-dug wells based on survey results (adapted from Uribe et al., 2004), and C) Frequency distribution for hydraulic conductivity $\left(K_{s}\right)$ values estimated in handdug wells.

$$
K_{S}=\frac{r^{2} R}{2 L\left(t_{75}-t_{25}\right)} \ln \left(\frac{y_{25}}{y_{75}}\right)
$$

where (as also defined in Figure 3) $r$ is the well radius (m), $L$ is the distance from the phreatic water level to the bottom of the well (m), $t_{25}$ is the time for the well to recover $25 \%$ of its initial water level $(\mathrm{min}), t_{75}$ is the time for the well to recover $75 \%$ of its initial water level (min), $y_{25}$ is the distance from the phreatic water level to the $25 \%$ recovery level $(\mathrm{m}), y_{75}$ is the distance from the phreatic water level to the $75 \%$ recovery level $(\mathrm{m})$, and $R$ is the effective radius where head differences are dissipated $(\mathrm{m})$ (Bouwer and Rice, 1976).

The effective radius $R$ can be estimated by the following equation:

$$
R=\frac{1.84+0.211 \mathrm{n}\left[\Lambda(L / r)^{2}\right]}{1+1.61[(D-L) / D)]^{1 / 2}(L / r)^{-5 / 8}}
$$

where $D$ is the thickness of the aquifer (Figure 3 ) and is a measurement of the capillarity of the soil as a function 
Soil surface

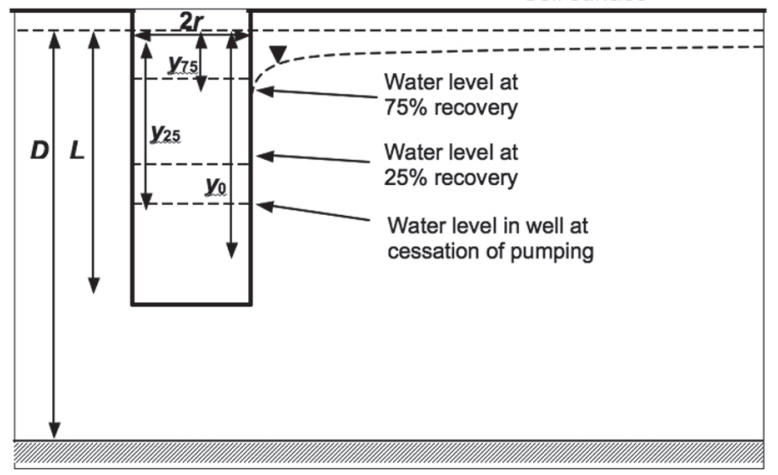

$r$ : well radius $(\mathrm{m}), L$ : distance from phreatic water level to the bottom of the well $(\mathrm{m}), y_{25}$ : distance from the phreatic water level to the $25 \%$ recovery level $(\mathrm{m}), y_{75}$ : distance from the phreatic water level to the $75 \%$ recovery level $(\mathrm{m})$, and $R$ : effective radius where head differences are dissipated $(\mathrm{m})$.

Figure 3. Dimensions used in the equations for estimating saturated hydraulic conductivity.

of texture based on soil texture (Rupp et al., 2001); for purposes of this study, $D$ was assumed to be equal to $L$. This assumption is liberal in terms of $K_{s}$. Equation [1] is valid for $2 \leq L / r \leq 20$. A value of $\Lambda=9.2 \mathrm{~m}$ was used for all wells, which corresponds to a silty-clay-loam material such as the one found in this area (Rupp et al., 2001).

\section{Estimation of available water in the hand-dug wells}

When the water level in a hand-dug well is maintained below the phreatic level, it is possible to estimate the flow rate $Q$ by knowing the hydraulic conductivity of the unconfined aquifer. Using an adapted equation from Thiem (1906), $Q$ can be predicted as:

$$
Q=2 \pi K_{S} L \frac{y}{R}
$$

where $R$ can be estimated for wide and relatively shallow wells using Equation [2]. Note that Equation [3] does not consider the lateral size of the aquifer, and thus imposes no limit on the aquifer to sustain a flow rate $Q$ through time. Therefore, Equation [3] can overestimate a well's productivity when the effective aquifer is small and when there are long periods without recharge.

Equations [1], [2], and [3] can be used to estimate the maximum feasible flow rate $Q_{\max }$ given an estimate of $K_{s}$, well dimensions, and minimum summertime phreatic levels. This allows us to compare the actual groundwater extraction rates $W$ and the maximum possible groundwater extraction rates $Q_{\max }$. This comparison can then be used to evaluate the potential for improving existing wells and/or new installations since the difference between $Q_{\max }$ and $W$ represents the amount of additional water that can be extracted from the wells.

To calculate well yield using Equation [3], $L$ was set equal to the minimum summertime water level measured from the well bottom (Figure 4a). This water level was obtained through observations made at least twice a
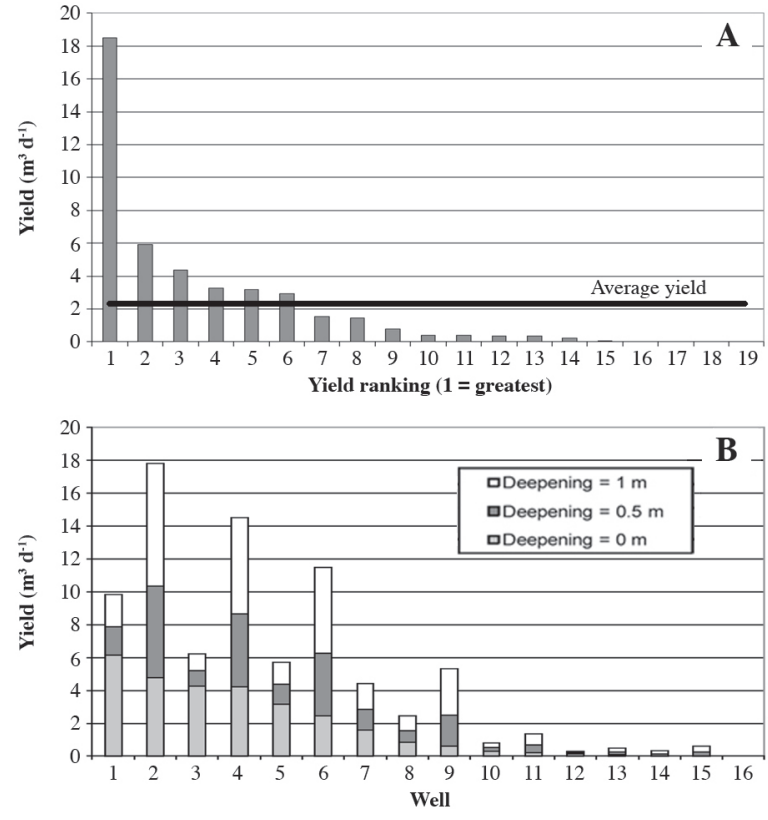

Note: If minimal water level in the well is $<0.5 \mathrm{~m}$, then yield is zero.

Figure 4. Predicted mid-summer yields. A) Wells restricted at the bottom by rock (not deepened). B) Wells without rock bases and simulated effects of deepening the wells by 0.5 and $1.0 \mathrm{~m}$. The wells are ordered by their current yield; this illustrates that some currently low-productivity wells could be significantly enhanced through relatively minor additional investment.

month and by consulting farmers to ensure that measured levels represented annual minima. It was also assumed that water could be obtained only if a minimum of $0.5 \mathrm{~m}$ of water above the well bottom remained during pumping (i.e., $y=0.5 \mathrm{~m}$ ) to account for the typical requirements of mechanical pumps (a conservative approach since many of these shallow wells are pumped with above-ground pumps that could completely empty the well). Thus, if a well's summertime water level was less than $0.5 \mathrm{~m}$, yield was considered to be zero. We further examined the effect of deepening the well by 0.5 and $1 \mathrm{~m}$ for those wells that were not restricted at the bottom by rock and assumed hydraulic conductivity was uniform with depth.

\section{RESULTS AND DISCUSSION}

The $K_{s}$ values obtained were classified as low (Villanueva and Iglesias, 1984) with a mean of $1.07 \mathrm{~m} \mathrm{~d}^{-1}$ and a standard deviation of $1.36 \mathrm{~m} \mathrm{~d}^{-1}$, which indicate high variability (Figures $2 \mathrm{c}$ and 5 ). Values are consistent with those found several hundred kilometers north of this site with mean hydraulic conductivities $42 \%$ of those found by Rupp et al. (2011) although the coefficients of variation were lower in this study $(\mathrm{cv}=1.27)$, that is, approximately one half those observed by Rupp et al. (2011) (cv=2.78), who sampled wells over a much larger area.

Of the 35 wells analyzed, 16 locations appear to be suitable candidates for additional excavation. Predictions 


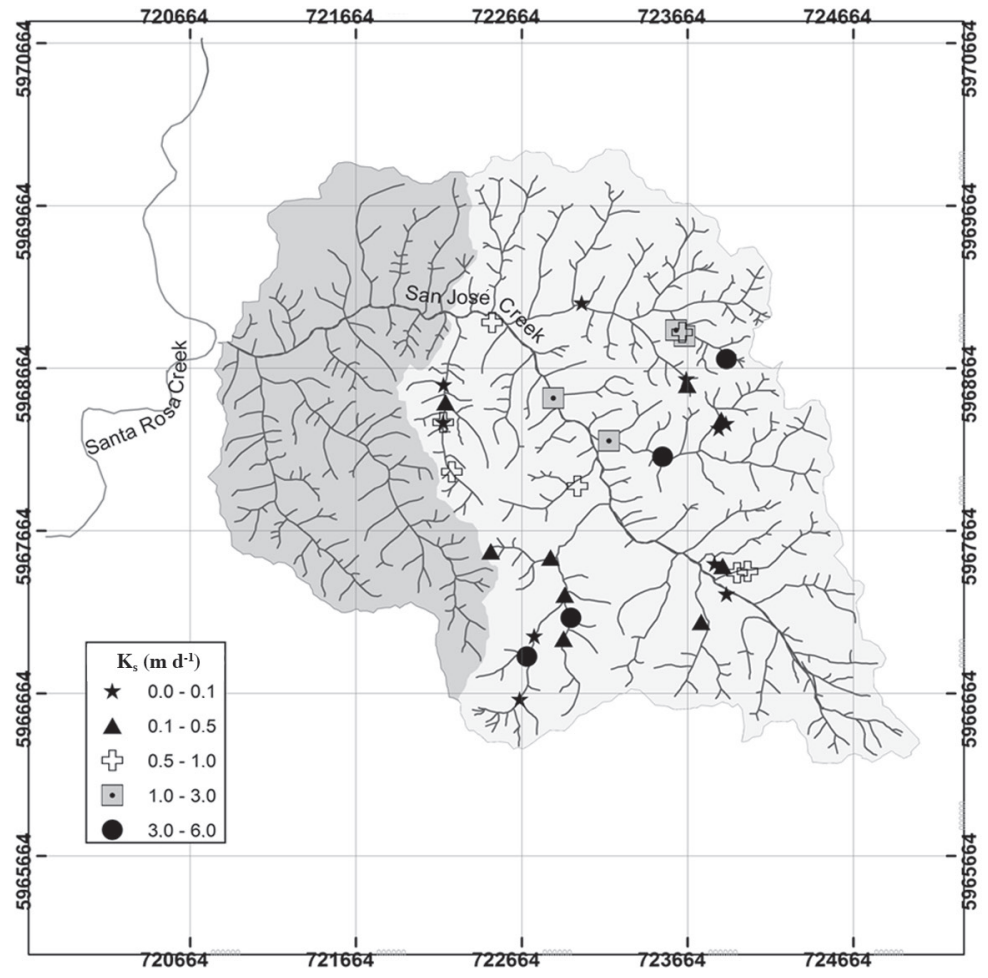

Figure 5. Spatial distribution of hydraulic conductivity $\left(\mathrm{m} \mathrm{d}^{-1}\right)$. UTM coordinates, Datum SAD 1969, Zone 18 South.

of yields from individual wells were summed to estimate the potential large-scale yield at catchment level. Results are presented in Figure 4 and Table 2.

The results of the present study suggest that wells in their current condition could produce a maximum yield $\left(Q_{\max }\right)$ of $0.008 \mathrm{~m} \mathrm{yr}^{-1}$. This rate is over four times larger than the current water usage ( $\mathrm{W}<0.002 \mathrm{~m} \mathrm{yr}^{-1}$ ), and so it appears that water yield from the current wells could be increased by at least $0.006 \mathrm{~m} \mathrm{yr}^{-1}$. Even greater yields may be possible by increasing the depth of the existing wells or by constructing additional wells. For example, extending the wells by $0.5 \mathrm{~m}$ could increase yields up to $0.02 \mathrm{~m} \mathrm{yr}^{-1}$. Uribe et al. (2003), on the basis of the Thornthwaite water balance, estimated groundwater recharge rates for this area as ranging between 0.0063 and $0.022 \mathrm{~m} \mathrm{yr}^{-1}$. Other studies determined recharge rates of 0.045 (Selker et al., 2000) and $0.027 \mathrm{~m} \mathrm{yr}^{-1}$ (González et al., 1999). Thus, extending the wells may not really produce as much water as predicted by Equations [1] to [3].

Our methods are based on an exact solution to a

Table 2. Simulation of available well yield under current conditions and with future deepening of wells.

\begin{tabular}{lccc}
\hline Feature & $\begin{array}{c}\text { Deepening } \\
=0 \mathrm{~m}\end{array}$ & $\begin{array}{c}\text { Deepening } \\
=0.5 \mathrm{~m}\end{array}$ & $\begin{array}{c}\text { Deepening } \\
=1 \mathrm{~m}\end{array}$ \\
\hline Mean per well, $\mathrm{m}^{3} \mathrm{~d}^{-1}$ & 3.3 & 8.1 & 12.8 \\
Number of wells & 49 & 49 & 49 \\
Potential yield, $\mathrm{m}^{3} \mathrm{yr}^{-1}$ & 59000 & 145000 & 229000 \\
Potential yield, $\mathrm{m} \mathrm{yr}^{-1}$ & 0.008 & 0.02 & 0.031 \\
\hline
\end{tabular}

physically realistic mathematical description of the aquifer conditions, but it should be kept in mind that we used assumptions that can limit predictive accuracy. First, we assumed that the wells were of homogeneous materials and that, when deepened, hydraulic characteristics would be the same as for shallower material. The validity of this assumption can only be established through field testing, which is suggested as a valuable continuation of this research theme. Another limitation of these results is that all the wells that did not have rock surfaces when probed would allow an additional meter of excavation. It would also be important to validate this in the field. With these limitations noted, we emphasize that the predictions are physically valid for the assumptions made, and are certainly sufficient to be used as indicators of opportunities for productive areas to explore groundwater development.

\section{CONCLUSIONS}

Estimated hydraulic conductivity varied between 0.04 and $5.14 \mathrm{~m} \mathrm{~d}^{-1}$ with a mean of $1.07 \mathrm{~m} \mathrm{~d}^{-1}$ and a coefficient of variation of 1.27. These estimated $K_{s}$ values were then combined with measurements from existing hand-dug wells in the region to simulate potential groundwater yields. The hand-dug wells were estimated to have a theoretical mean potential yield of $0.008 \mathrm{~m} \mathrm{yr}^{-1}$ in their current condition; this is more than four times the estimated 
current water usage by farmers in the region and indicates that most local farmers are currently pumping well below capacity. Furthermore, extending certain wells by $0.5 \mathrm{~m}$ could increase potential groundwater yield to more than $0.02 \mathrm{~m} \mathrm{yr}^{-1}$ although this rate may not be feasible given the overall low rates of groundwater recharge observed in the area.

\section{LITERATURE CITED}

Bizama, G. 1998. Geología del cuadrángulo Yumbel (3700’-375' S, $72^{\circ} 30^{\prime}-72^{\circ} 45^{\prime}$ W) VIII Región del Bío-Bío, Chile. 103 p. Memoria de Título Geólogo. Facultad de Ciencias Químicas, Universidad de Concepción, Concepción, Chile.

Bouwer, H., and R.C. Rice. 1976. A slug test for determining hydraulic conductivity of unconfined aquifers with completely or partially penetrating wells. Water Resources Research 12:423428.

CNR-CIREN-CORFO. 1997. Cartografía de la evapotranspiración potencial en Chile. Comisión Nacional de Riego (CNR), Centro de Información de Recursos Naturales (CIREN), Corporación de Fomento de la Producción (CORFO), Santiago, Chile.

Çimen, M. 2005. Type curves for unsteady flow to a largediameter well in patchy aquifers. Journal of Hydrologic Engineering 10:200-204

CIREN. 1999. Estudio agrológico VIII Región. Descripciones de suelos: Materiales y símbolos. Publicación $\mathrm{N}^{\circ} 121.586$ p. Centro de Información de Recursos Naturales (CIREN), Santiago, Chile.

Del Pozo, A., y P. del Canto. 1999. Áreas Agroclimáticas y sistemas productivos en la VII y VIII regiones. Serie Quilamapu 113 116 p. áreas agroclimáticas y sistemas productivos en la VII y VIII regiones. Serie Quilamapu Instituto de Investigaciones Agropecuarias, INIA Quilamapu, Chillán Chile.

González, L., M. Mardones, A. Silva, y E. Campos. 1999. Hidrogeoquímica y comportamiento del agua subterránea en la cuenca del río Claro, Región del Biobío, Chile. Revista Geológica de Chile 26:145-157.

MacDonald, A.M., J.A. Barker, and J. Davies. 2008. The bailer test: a simple effective pumping test for assessing borehole success. Hydrogeology Journal 16:1065-1075.
Mace, R.E. 1999. Estimation of hydraulic conductivity in largediameter, hand-dugwells using slug-test methods. Journal of Hydrology 219:34-45.

Pérez, C., y J. González. 2001. Diagnóstico sobre el estado de degradación del recurso suelo en el país. Boletín INIA $\mathrm{N}^{\circ} 15$. 194 p. Instituto de Investigaciones Agropecuarias INIA, Chillán, Chile.

Rupp, D., O. Reckmann, J. Vergara, H. Uribe, and J. Selker. 2011 Unconfined aquifer permeability near hand-dug wells in the secano costero and interior, Libertador General Bernardo O'Higgins Region, Chile. Chilean Journal of Agricultural Research 71:267274.

Rupp, D., J. Selker, and J. Simunek. 2001. A modification to the Bower and Rice method of slug-test analysis for large-diameter, hand-dug wells. Ground Water 39:308-314.

Selker, J., D. Rupp, M. Leñam, y H. Uribe. 2000. Estudio hidrológico en el Secano Interior. Resultados preliminares del proyecto piloto en Portezuelo. Informe Técnico de Riego. 41 p. Instituto de Investigaciones Agropecuarias, INIA Quilamapu, Chillán Chile.

Stewart, R., D. Rupp, M. Abou Najm, J. Lane, H. Uribe, J. Arumí, et al. 2014. Hillslope runoff thresholds in shrink-swell clay soils Hydrological Processes. doi:10.1002/hyp.10165.

Thiem, G. 1906. Hydrologische methoden. Gebhardt, Leipzig, Germany.

Uribe, H., J. Arumi, L. González, y L. Salgado. 2003. Balances hidrológicos para estimar recarga de acuíferos en el Secano Interior, Chile. Ingeniería Hidráulica en México 23(3):17-28.

Uribe, H., O. Lagos, D. Rupp, y Y. Okuda. 2004. Estudio de disponibilidad de aguas subterráneas a nivel de la cuenca de San José, Ninhue. In Uribe, H., C. Pérez y Y. Okuda (eds.) Boletín Recursos Hídricos y Manejo del Agua para un Desarrollo Sustentable del Secano. Boletín INIA $N^{\circ} 123$. Instituto de Investigaciones Agropecuarias, INIA Quilamapu, Chillán, Chile.

Villanueva, M., y A. Iglesias. 1984. Pozos y acuíferos. Técnicas de evaluación mediante ensayos de bombeo. 426 p. Instituto Geológico y Minero de España, División Aguas Subterráneas, Madrid, España.

Yang, S.Y., and H.D. Yeh. 2004. A simple approach using Bouwer and Rice's method for slug test data analysis. Ground Water 42:781-784. 